\title{
OPTIMIZE THE CONDITION FOR ENZYMATIC DEGUMMING OF CRUDE SOYBEAN OIL
}

\author{
M Prabhaharan ${ }^{1 *}$ and SK Rakshit ${ }^{2}$ \\ ${ }^{1}$ Agricultural Engineering, Faculty of Agriculture, University of Jaffna \\ ${ }^{2}$ Professor, Food Engineering Division, School of SERD, AIT, Thailand
}

\begin{abstract}
High phosphatide containing oils like soybean oil, have two types of phosphatide (gum) namely, the hydratable and non-hydratable. Simple water degumming will not remove non-hydratable gums. Water degumming alone is not satisfactorily to reduce the gum content below $10 \mathrm{ppm}$ to enable the physical refining. Therefore enzymatic process is used together with water degumming. The enzymatic degumming process was employed to reduce the level of phosphatide $(P)$ less than $10 \mathrm{ppm}$ in $10 \mathrm{~h}$ of duration without mixing. A combined degumming process a normal mixing speedup the reduction of the gum level to less than 10ppm in $7 \mathrm{~h}$ of mixing duration, while a combined degumming process exhibiting a normal mixing followed by initial emulsification $(15 \mathrm{~min})$ speedup the reduction of the gum level to less than $10 \mathrm{ppm}$ in $6 \mathrm{~h}$ of mixing duration. On the other hand initial emulsification $(15 \mathrm{~min})$ with normal mixing (2000 rpm) at $2 \mathrm{ml}$ enzyme level gave the same result $5 \mathrm{~h}$. Gum level of the water degummed oil $(150 \mathrm{ppm}$ to $180 \mathrm{ppm})$, which was used as a starting material for the two-step process was efficiently reduced to less than $10 \mathrm{ppm}$ within $4 \mathrm{~h}$. Initial emulsification $(15 \mathrm{~min})$ with normal mixing $(1000 \mathrm{rpm}), 1 \mathrm{ml}$ enzyme level the water degummed oil gave the phosphatide $(P)$ less than $10 \mathrm{ppm} 3 \mathrm{~h}$. This condition is thus most preferable. Among these process the initial emulsification with normal mixing was given better result than the normal mixing, and two step process were faster than the process of combined.
\end{abstract}

\section{INTRODUCTION}

Degumming is an important step in oil refining process as it removes phosphatide (gum) along with some other unwanted minor compounds without destroying the beneficial ones. Gums tend to produce high refining losses, foaming, settling and discoloration of oil in processing and storage (Eickhoff 2000).

Several degumming concepts have been introduced in recent years to achieve the required low phosphatide content required for physical refining, this include acid degumming (Phosphoric acid and organic acids). Unfortunately these methods have several disadvantages including corrosion of processing equipment, lower the value by-product and environmental hazards (Racicot and Handel 1983).

There are two types of phospholipids present in vegetable oils namely the hydratable and nonhydratable. Simple water degumming will not remove non-hydratable gums or pro-oxidant metals to levels which do not impaire colour and oxidative stability. Hence the enzymatic degumming is very important (List et al. 1993).

The microbial enzyme Lecitase Novo enzymatic degumming is cost-efficient compared to chemical refining and other physical refining processes. Physical refining however requires phosphatide content to be less than 10ppm as they affect the vacuum distillation process at higher level. Enzymatic degumming process achieve this level are required to remove the non-hydratable phospholipids (Dahlke and Buchold 1995).

\section{The Objectives of this study}

Optimize the conditions of degumming process gum level below 10ppm using microbial enzymes (Lecitase Novo) in crude soybean oil.

\section{MATERIALS AND METHODS}

\section{Materials}

Crude soy oil was obtained from Vegetable oil products Co. Ltd and enzyme Lecitase(r) Novo is an enzyme of Novo Nordisk from The East Asiatic Public Company Limited. Lecitase Novo is a carboxylic ester hydrolase produced by submerged fermentation of a genetically modified Aspergillus oryzae microorganism (Novo Nordisk 2000).

The following equipments $\&$ instruments were used. Spectrophotometer UV2-200, Shaker with water bath, mixing heads with control panel and emulsifier.

\section{Methodology}

Combined Process of enzymatic degumming of crude soybean oil

$500 \mathrm{ml}$ of crude oil or degummed was taken into the reactor, which was kept at about the temperature needed for the specific reaction $\left(40^{\circ} \mathrm{C}\right)$ The lab mixing head was turned on that the oil starts to

\footnotetext{
*Corresponding author: aenpraba@gmail.com

Paper presented at the 2nd National Symposium, Faculty of Agriculture, University of Ruhuna
} 
circulate from the reactor to the emulsifier and back to the reactor. The pre-treatment period starts $(\mathrm{t}=0)$ with addition of $1.5 \%(\mathrm{v} / \mathrm{v})$ water was added Just after this buffer solution $1.5 \%(\mathrm{v} / \mathrm{v})$ were added to the system, at $(\mathrm{t}=1 \mathrm{~h}) 2 \mathrm{ml}$ samples are drawn for phosphorus analysis and continue every $1 \mathrm{~h}$ up to gum level less than 10ppm.

Combined process crude oil was taken and degummed as described as single step degumming process. In this experiment the potential of a combined degumming process which, using water and enzyme (Lecitase Novo) for the removal the hydratable and non-hydratable gum simultaneously. In this study, buffer solution and phospholipase A1 (Lecitase Novo) enzyme were used for hydration and hydrolysis of phospholipids respectively in soybean oil. The degumming process depends on the following operational parameters to achieve the level of phosphatide below 10ppm to enable the physical refining.

The emulsification process were performed to investigate the gum removal under the optimum conditions attained in this experiment. initial, every two-hour and every hour emulsification were further studied to be processes while compared to the normal mixing at an enzyme level of $1 \mathrm{ml}$ and speed of mixing levels of 500, 1000 and 2000rpm in other period (simple mixing).

Two-step process of enzymatic degumming of crude soybean oil.

This part of the studies involves water and enzymatic degumming performed separately in which $1.5 \%$ of water was added initially (an amount sufficient for the removal of hydratable gum at a considerable amount under the optimized conditions during the water degumming experiment) followed by the addition of $1.5 \%$ of water containing the buffer ( $0.1 \mathrm{M}$ citrate buffer) and enzyme (Lecitase Novo). The final amount of water was kept constant (3\%). Degummed oil sample was taken for P determination. Water degumming is the simplest form of phosphatide reduction. However, only hydratable gums can be removed. Degumming were performed to investigate the gum removal under the optimum conditions attained in this experiment

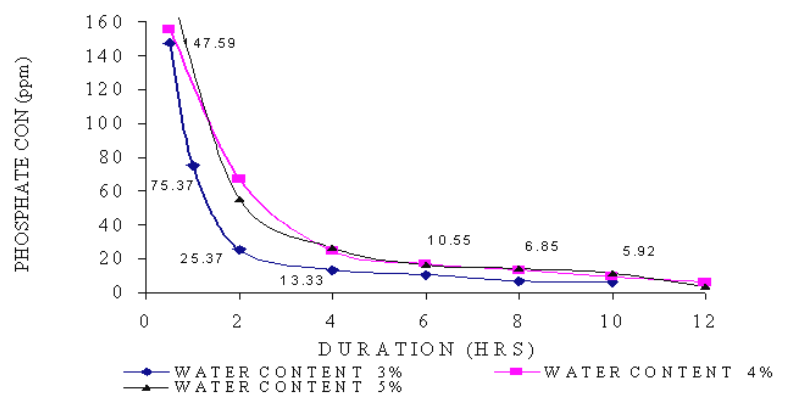

Figure 1: Water amount in the enzymatic egumming of crude oil $(500 \mathrm{ml}$ crude oil, $1 \mathrm{ml}$ enzyme, normal mixing $1000 \mathrm{rpm}$ at $40^{\circ} \mathrm{C}$ ) were percentage of water $(\mathrm{v} / \mathrm{v})$, degumming temperature $\left({ }^{\circ} \mathrm{C}\right)$, speed of mixing $(\mathrm{rpm})$ and duration of mixing (h)

\section{RESULTS AND DISCUSSION}

Enzymatic degumming of crude soybean oil (Combined process)

Simultaneous removal of hydratable and nonhydratable gum was consumed more than $10 \mathrm{~h}$ time to reached the target level of phosphatide (Gum) less than 10ppm, in other hand stirrer mixing was involved in this process the gum removal was faster, which consumed $7 \mathrm{~h}$ of mixing duration under the conditions of $500 \mathrm{ml}$ crude oil, $1 \mathrm{ml}$ enzyme, $3 \%$ buffer solution, mixing speed of $1000 \mathrm{rpm}$ at $40^{\circ} \mathrm{C}$.

It was found that a $3 \%$ total water level $(1.5 \%$ water and $1.5 \%$ buffer) enhanced the degumming process Fig. 1. Although it is after 9 and $10 \mathrm{~h}$ of mixing the degumming process conducted using a total water levels of $4 \%$ and $5 \%$ provided the same phosphatide level ( $\mathrm{p}<10 \mathrm{ppm})$.

\section{Mode of mixing in enzymatic degumming process of crude oil}

Further improvement in simultaneous gum removal was performed by stirrer mixing coupled with emulsification processes at initial stage $(15 \mathrm{~min})$ the gum removal was faster it consumed $6 \mathrm{~h}$ duration. (Fig. 2).

Further investigation was analyzed in various strength of enzyme $(0.5,1.0$, and $2 \mathrm{ml})$, mixing speeds $(500,1000$ and 2000) and buffer strength (3, $4 \& 5 \%)$ Fig. 3 shows that 2000rpm and $2 \mathrm{ml}$ enzyme level performed the gum removal were faster but the performance of gum removal was economically ineffective (Fig. 3).

\section{Enzymatic degumming of water degummed oil (two step process)}

Combined process was compared with two step processes, the later one faster than the first one; because of enzyme only react with non-hydratable gum part. (Fig. 4)

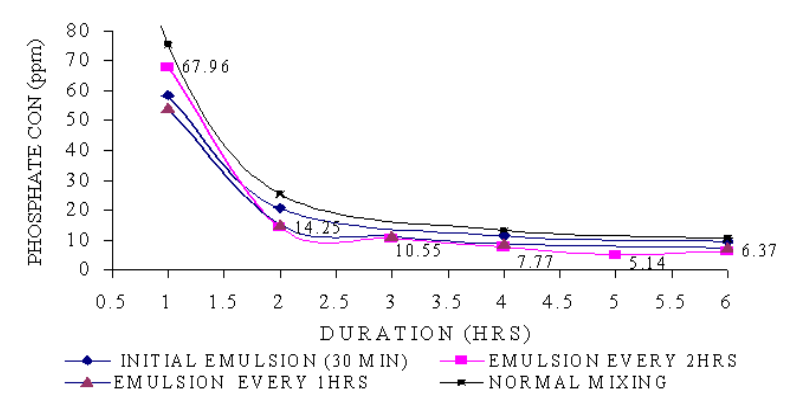

Figure 2: Mode of mixing in enzymatic degumming process of crude oil $(500 \mathrm{ml}$ Crude oil, $3.0 \%$ water \& buffer, $1 \mathrm{ml}$ enzyme, $1000 \mathrm{rpm}$ at $40^{\circ} \mathrm{C}$ ) 


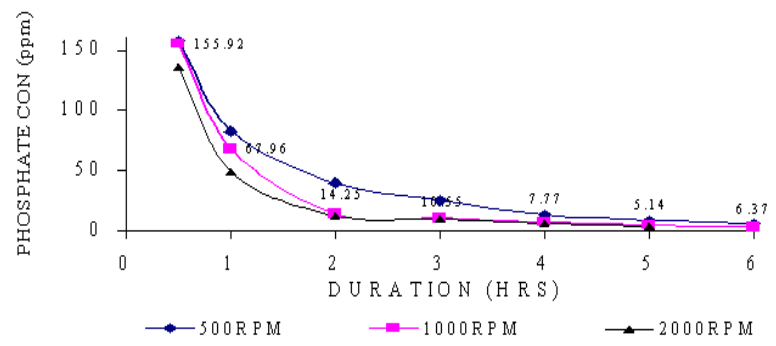

Figure 3: Mixing speed and initial emulsion (15 min) in combine process $(500 \mathrm{ml}$ crude oil, $1.5 \%$ water, $1.5 \%$ buffer, $2 \mathrm{ml}$ enzyme at $40^{\circ} \mathrm{C}$ )

Two stage process the gum removal was employed in two stages, initially gum was removed by water up-to level of residual gum 150-180ppm, later process gum removal was more faster it consumed $4 \mathrm{~h}$ mixing duration.

\section{Water degumming process}

As is presented in Fig. 5 a water level increment from $1 \%$ to $3 \%$ at $500 \mathrm{rpm}$ decreased the phosphate concentration of the oil up to $150-180 \mathrm{ppm}$ after $30 \mathrm{~min}$ of mixing duration and remained almost constant afterwards. Among the temperatures tested $40^{\circ} \mathrm{C}$ slightly favored the water degumming process.

\section{Mixing mode in the two step enzymatic degumming process}

While determining the enzyme concentration required for the two step degumming process enzyme performed the gum removal were not significant. Studies on mixing conditions while using the two step degumming process on the other hand revealed that 2000rpm reduced phosphate to the required level faster while 1000rpm took little longer hours (Fig. 6).

Optimization conditions of enzymatic degumming of water degummed oil the gum removal was so-faster it consumed $3 \mathrm{~h}$ of duration Fig. 6, with the conditions of initial emulsification (15min) with stirrer mixing (1000rpm) 500ml crude oil, $1 \mathrm{ml}$ enzyme, $3 \%$ buffer solution, at $40^{\circ} \mathrm{C}$.

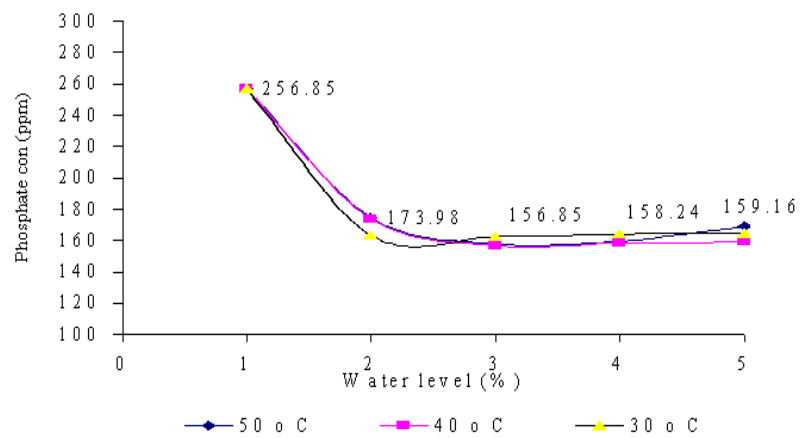

Figure 5: Water level and temperature in water degumming of crude oil. $(500 \mathrm{ml}$ crude oil at $500 \mathrm{rpm}$, $30 \mathrm{~min})$

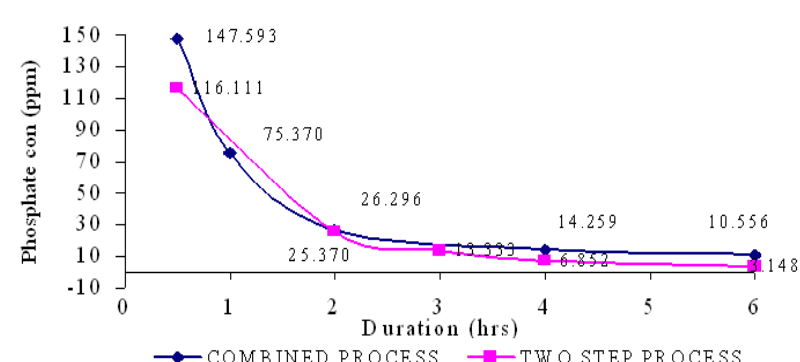

Figure 4: Combined and two step Enzymatic degumming $(500 \mathrm{ml}$ oil, $1.5 \%$ buffer, $1 \mathrm{ml}$ enzyme, $1000 \mathrm{rpm}$, at $40^{\circ} \mathrm{C}$ )

\section{CONCLUSION}

Simultaneous removal of hydratable and non hydra table gum was consumed more than $10 \mathrm{~h}$ to reach the target level of phosphatide (Gum) less than $10 \mathrm{ppm}$.

In stirrer involved mixing of degumming process, the reduction of gum was less than 10ppm at $7 \mathrm{~h}$ of mixing duration. Normal mixing followed by initial emulsification $(15 \mathrm{~min})$ speeded the reduction of the gum level to less than 10ppm at $6 \mathrm{~h}$ of mixing duration. This was achieved in while $1 \mathrm{ml}$ enzyme was used per $500 \mathrm{ml}$ crude oil at $1.5 \%$ water, $1.5 \%$ buffer level at $40^{\circ} \mathrm{C}$ with normal mixing (1000rpm). On the other initial emulsification (15min) with normal mixing (2000rpm) at $2 \mathrm{ml}$ enzyme level gave the same result at 5 hours. Further investigation was analyzed in various strength of enzyme $(0.5,1.0$, and $2 \mathrm{ml})$, mixing speeds $(500,1000$ and $2000)$ and buffer strength (3, $4 \& 5 \%)$ Fig. 3 shows that $2000 \mathrm{rpm}$ and $2 \mathrm{ml}$ enzyme level performed the gum removal were faster but the performance of gum removal, which was economically ineffective.

During the water degumming process $3 \%$ water level, $40^{\circ} \mathrm{C}, 30 \mathrm{~min}$ of mixing duration at $500 \mathrm{rpm}$ efficiently reduced the level of phosphatide. The gum level of the water degummed oil (160ppm to $180 \mathrm{ppm}$ ), which was used as a starting material for the two-step process was efficiently reduced to less than 10ppm within $4 \mathrm{~h}$. This was achieved in $1 \mathrm{ml}$

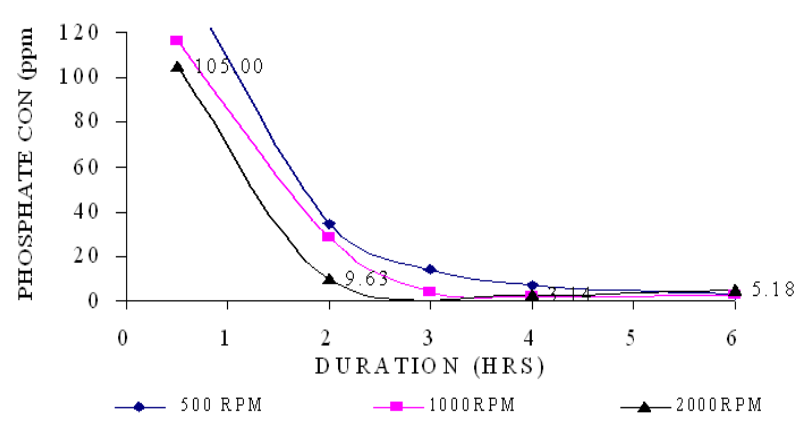

Figure 6: Mixing speed in degumming of water degummed oil, $500 \mathrm{ml}$ Degummed oil $1.5 \%$ buffer, $1 \mathrm{ml}$ enzyme, at $40^{\circ} \mathrm{C}$ initial emulsification $(15 \mathrm{~min})$ 
enzyme per $500 \mathrm{ml}$ water degummed oil in $1.5 \%$ buffer at $40^{\circ} \mathrm{C}$, normal mixing (1000rpm). On the other initial emulsification $(15 \mathrm{~min})$ with normal mixing (1000rpm) at $1 \mathrm{ml}$ enzyme level gave the same result at $3 \mathrm{~h}$. This condition is thus most preferable.

Two step process were faster than the process of combined one, because of hydratable gum part already removed in two step process so enzyme only react with non-hydratable part. Among this process the initial emulsification with normal mixing was gave better result than the normal mixing, because of emulsification process was break down the oil and gum particle into tiny pieces, so enzyme reaction was more active.

\section{REFERENCES}

Carelle AAMIV and Crapiste GH 1997 'Quantitative determination of phospholipids in sun flower oil', JAOCS, 74:5511-514.

Dahlke K and Buchold H 1995 'first the enzymatic degumming process' Inform, 6:12, 1284-1291.

Eickhoff KP 2000 'Degumming process in edible oil Industry' World Conference Proceedings on Edible Oils and Fat Processing - Basic Principles and Modern Practices, Edited by S.C. Singhal, AOCS, Champaign, 2000.

List GR, Avellaneda JM and TL Mounts 1993 Refining of soybean oil' JAOCS. 58: 892.
Novo Nordisk 2000 'Lecitase novo enzyme product sheet' Available online hills: www.mynovozy m.2001-06954-n.html [down loaded: 11 2001]

Racicot LD and AP Handel 1983 'Degumming of soybean oil: Quantitative analysis of Phospholipids in crude and degummed oil 1, 2 JA OCS 60: $6 ; 1098-1101$.

Edible oil refining systems providing caustic refining, bleaching' available online www. crowniron.com/refinina.html [downloaded: 2. 2 2002]

Soya oil degumming available online www.ag.uiuc. edu/archives/experts/utilization/html. [down loaded: 22 2002] 